\title{
乳癌症例におけるデジタルマンモグラフィモニター診断と スクリーンフィルム診断の比較検討
}

福井県立病院外科 ${ }^{1)}$ ，同放射線科 ${ }^{2)}$ ，同臨床病理 ${ }^{3)}$

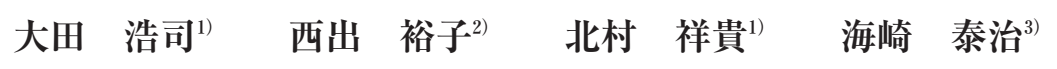

\begin{abstract}
要旨: Full-field digital mammography(以下 FFDM)の特性おょび screen film mammography (以下 SFM) に対する非劣勢を調査することを目的に, 術前に両モダリティで撮影 された乳癌64例を対象に読影結果を比較した。FFDMは直接変換方式を採用し，モニ夕 一は $5 \mathrm{M}$ の LCD を用いて二重読影を行った。比較項目は, 腫瘤辺縁, 随伴所見, カテゴ リーとした。FFDM で7.8\%, SFM で10.9\%が同定困難であった。カテゴリー4, 5 と診断 された症例は FFDM で78.2\%, SFM で70.3\%であり，FFDMでより正確な診断がなされ ていた。腫瘤の辺縁診断では, FFDM で境界不明瞭が全体の $25.7 \%$ あっったのに対し, SFM では $40.0 \%$ と高值であった。さらに, 癌としての特異度の高い微細分葉, 鋸歯状, スピキ ユラに関しては, FFDM で計 $65.7 \%$, SFM で計 $45.7 \%$ と前者でより詳細な診断がなされ ていた。随伴所見では, FFDM で59.4\%に認めたが, SFMでは45.3\%と少ない傾向にあ った。同定不能症例では, FFDM では随伴所見のない等濃度の DCIS が60.0\%, SFM で は小さい浸潤癌が85.7\%であった。FFDM では, 生命予後に関わる浸潤癌の検出力は SFM を凌駕しており，FFDM の特性，非劣勢を証明できたものと思われる。

索引用語：デジタルマンモグラフィ, スクリーンフィルムマンモグラフィ, 乳癌
\end{abstract}

\section{緒 言}

医療の現場におけるIT 化は電子カルテやフィルム レス化という形で広く普及し, その一環として画像モ ダリティのデジタル化が急速に進んでいる。マンモグ ラフィも例外ではなく，今後は検診機関でもスクリー ンフィルム系マンモグラフィ(以下 SFM)からデジタ ルマンモグラフィに移行することが予想される。マン モグラフィ撮影装置の技術革新は著しく, DMIST ${ }^{1)}$ Oslo II study ${ }^{2)}$ な゙の大規模臨床試験にて検診に対す る有効性, 安全性が実証されたが, デジタル画像, 特 にモニター診断に関してはその独特の画像ゆえに SFM からの移行期には読影者の違和感は否定でき ず, 実際 learning curve が存在すると言われている ${ }^{3)} 。$ 当院では2005年 8 月に flat panel detector 方式による デジタルマンモグラフィ (full field digital mammography, 以下 FFDM) を導入し，約 4 年が経過した。

別冊請求先 : T 910-8526 福井市四ツ井2-8-1 福井県立病院外科 大田浩司 e-mail:kouji0470326@yahoo.co.jp
今回われわれは, FFDM の特性やSFM に対する非劣 勢を調査することを目的に，術前に両モダリティで撮 影された乳癌症例を対象に両読影結果を比較した。

\section{1. 対象および方法}

05年 8 月から09年 6 月に両モダリティで撮影された 乳癌症例91例中，石灰化が主体である症例を除外した 64例を対象とした。これら64例はすべて癌の診断がな された後に両モダリティを個別に再読影し, 今回の基 本データとした。また，スポット撮影，超音波および MRI や病理所見は参考にせず，極力マンモグラフィ の所見のみを重視するよう心がけた。撮影に際し， informed consentを基本とした。SFM 撮影装置は senographe DMR, 現像機は Kodak minilordor200P, 現像時間は123秒, 現像温度は33.3度である。FFDM 撮影装置は直接変換方式を採用した。ピクセルサイズ は70 $\mu \mathrm{m}$ ，照射サイズは $24 \times 29 \mathrm{~cm} ， 1$ 枚あたりのデー 夕量は約 $23 \mathrm{MB}$ である。読影モニターは $5 \mathrm{M}$ の LCD を用い，明室コントラストを重視した環境下で，濃度 や階調は状況に応じて調整しながら読影した。なお, FFDM，SFM いずれも精中委A，B有資格医師によ 
る二重読影を基本とした。今回の比較項目は，腫瘤辺 縁の性状, 随伴所見の有無 (構築異常, 病変内石疢化, 皮膚肥厚)，カテゴリーとし，これらを病理と照合し た。

\section{2. 結 果}

患者背景を表 1 に示す。平均年齢は59.1歳, 平均腫 瘍径は2.5cm であった。64例中, 非浸潤性乳管癌は 8 例 $(12.5 \%), \mathrm{T} 1$ は 32 例 $(50.0 \%), \mathrm{T} 2$ は 20 例 (31.3\%)，T3は 4 例 (6.3\%)であった。ちなみにリン パ節転移陽性例は21例 (32.8\%)であった。カテゴリー 診断では， 1 もしは 2 と診断された症例，つまり病 変の同定が不可能であった例数はFFDM で 5 例 (7.8\%), SFM で7例 (10.9\%)であり, 後者で多い傾 向があった (表 2,3$)$ 。一方, カテゴリー4もしくは 5 と診断された症例, つまり悪性を強く疑った例数は FFDM で50例(78.2\%), SFM で45例(70.3\%)であり, FFDM でより正確なカテゴリー診断がなされていた

表 1. 患者背景

\begin{tabular}{l|c}
\hline 平均年齢 & 59.1 歳 $(35$ 歳 84歳) \\
平均腫瘍径 & $2.5 \mathrm{~cm}(0.4 \sim 12.0 \mathrm{~cm})$ \\
$\mathrm{T} 1$ & 32 例 $(50.0 \%)$ \\
$\mathrm{T} 2$ & 20 例 $(32.3 \%)$ \\
$\mathrm{T} 3$ & 4 例 $(6.3 \%)$ \\
非浸潤性乳管癌 & 8 例 $(12.5 \%)$ \\
硬癌 & 28 例 $(43.8 \%)$ \\
乳頭腺管癌 & 11 例 $(17.2 \%)$ \\
充実腺管癌 & 8 例 $(12.5 \%)$ \\
特殊型 & 9 例 $(14.1 \%)$ \\
リンパ節転移 & 21 例 $(32.8 \%)$ \\
\hline
\end{tabular}

(図 1)。背景乳腺別に, SFM のカテゴリーを縦軸に， FFDM を横軸にした結果が図 2 である。脂肪性およ び乳腺散在例においては，両モダリティのカテゴリー 一致率は $71.7 \%$ と高かったが, 不均一・高濃度乳腺症 例では一致率は $55.6 \%$ と低く, さらにFFDM 側に多 くプロットされていた(図 2)。つまり，乳腺濃度が高 くなるにつれ，癌の診断は FFDM で SFM より正確に なると判断された。次に腫瘤辺縁の結果を図 3 に示 す。ちなみに腫瘤と認識された症例は両モダリティと もに35例であった。FFDM では境界不明瞭が全体の $25.7 \%$ であったのに対し，SFM では $40.0 \%$ と高值で あった。さらに, 癌としての特異度のより高い微細分 葉状(鋸歯状)，スピキュラに関しては，FFDMで計 65.7\%, SFM で計 $45.7 \%$ と, FFDMでより詳細な辺 縁診断がなされていた。さらに両モダリティでともに 腫瘤と診断された30例において辺縁所見を比較した (図 4)。8例の不一致例を認め, うち 7 例において FFDM でよりカテゴリーの高い辺縁診断がなされて いた。随伴所見に関しては, 構築の乱れ, 病変内の微 小石灰化，および皮膚の肥厚が主な所見であった。 FFDM では38例 (59.4\%) に随伴所見を認めたが, SFM では29例 (45.3\%) と少ない傾向にあった（図 5)。表 2, 3 にそれぞれ FFDM，SFM の同定不能症例を提示す る。FFDMでは石疢化などの随伴所見のない, 陰影 のみの DCIS が全体の $60.0 \%$ と多い傾向にあったが, SFM では比較的腫瘍径の小さい浸潤癌が多く, $85.7 \%$ であった。なお，FFDMで同定不可能であった上記 DCISに関しては，階調，濃度をモニター上で調整す ることにより陰影としては同定できたが，病変として の認識は困難であった。FFDM，SFM 同定不能例の

表 2. FFDM 同定不能症例

\begin{tabular}{|c|c|c|c|c|c|}
\hline & 年齢 & 背景乳腺 & 腫瘍径 & 組織型 & SFM の所見 \\
\hline 症例 1 & 66歳 & 乳腺散在 & $3.8 \mathrm{~cm}$ & DCIS & $\mathrm{FAD}(3)$ \\
\hline 症例 2 & 46歳 & 不均一高濃度 & $2.8 \mathrm{~cm}$ & DCIS & 明瞭腫瘤(3) \\
\hline 症例 3 & 44歳 & 不均一高濃度 & $1.8 \mathrm{~cm}$ & DCIS & 不明瞭腫瘤(4) \\
\hline 症例 4 & 60歳 & 乳腺散在 & $2.3 \mathrm{~cm}$ & 小葉癌 & 構築の乱れ(3) \\
\hline 症例 5 & 75歳 & 乳腺散在 & $0.9 \mathrm{~cm}$ & 硬癌 & $\mathrm{FAD}(3)$ \\
\hline
\end{tabular}

表 3. SFM 同定不能症例

\begin{tabular}{|c|c|c|c|c|c|}
\hline & 年齢 & 背景乳腺 & 腫瘍径 & 組織型 & FFDM の所見 \\
\hline 症例 1 & 53歳 & 不均一高濃度 & $2.1 \mathrm{~cm}$ & 硬癌 & FAD＋構築(3) \\
\hline 症例 2 & 46歳 & 乳腺散在 & $2.1 \mathrm{~cm}$ & DCIS & $\mathrm{FAD}+$ 石灰化(3) \\
\hline 症例 3 & 45歳 & 不均一高濃度 & $1.8 \mathrm{~cm}$ & 硬癌 & 構築の乱れ(4) \\
\hline 症例 4 & 35歳 & 高濃度 ～～～～～ & $0.7 \mathrm{~cm}$ & 硬癌 & $\mathrm{FAD}+$ 石灰化(3) \\
\hline 症例 5 & 45歳 & 不均一高濃度 & $1.5 \mathrm{~cm}$ & 乳頭腺管癌 & 石灰化＋構築(3) \\
\hline 症例 6 & 81歳 & 乳腺散在 & $1.3 \mathrm{~cm}$ & 乳頭腺管癌 & $\mathrm{FAD}+$ 構築(4) \\
\hline 症例 7 & 55歳 & 乳腺散在 & $0.4 \mathrm{~cm}$ & 硬癌 & スピキュラ腫瘤(5) \\
\hline
\end{tabular}




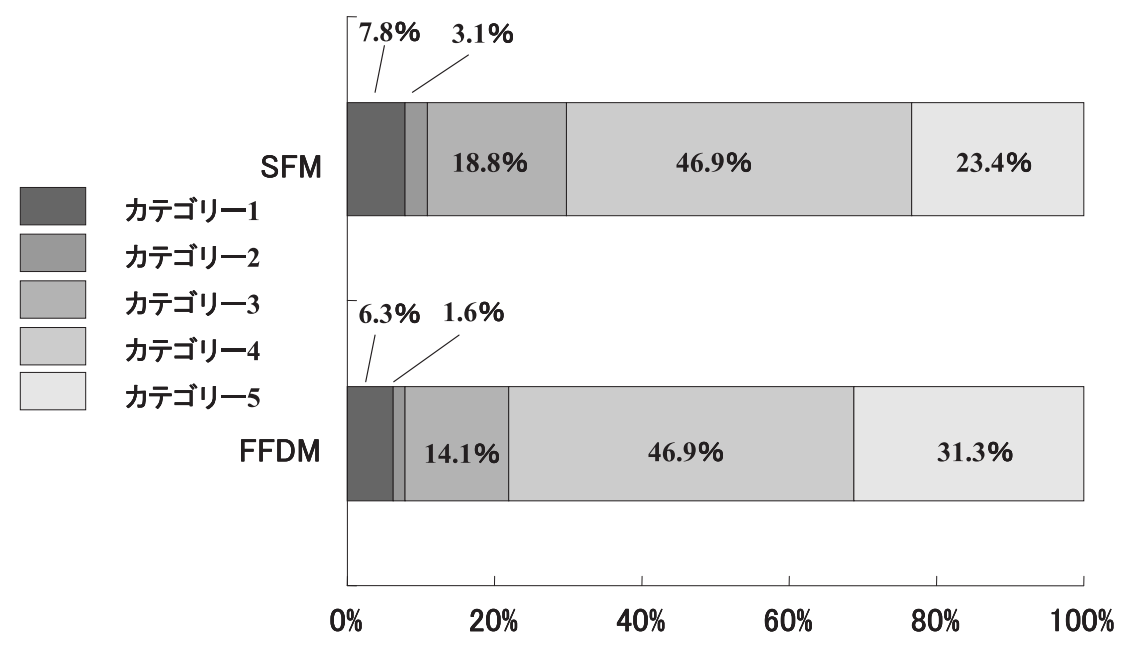

図1.両モダリティにおけるカテゴリー診断

（脂肪性および乳腺散在）

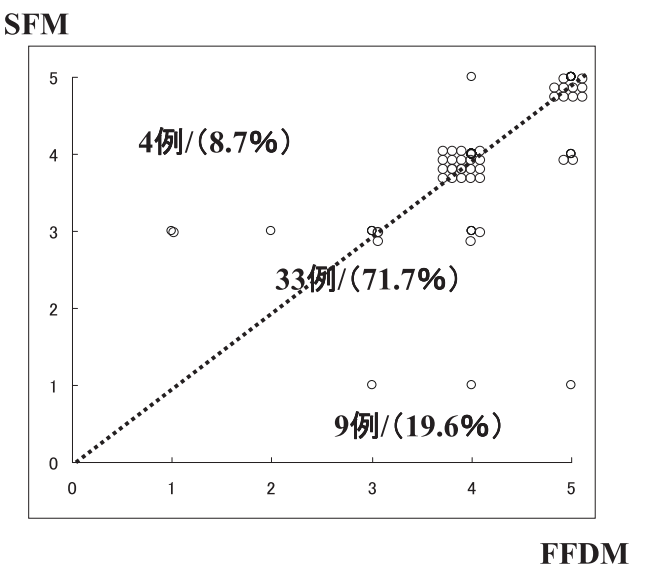

(不均一および高濃度)

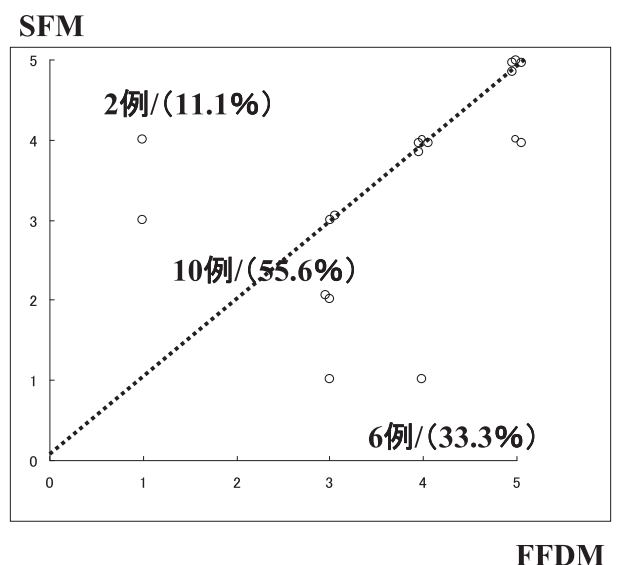

図2. 両モダリティ間のカテゴリー分布

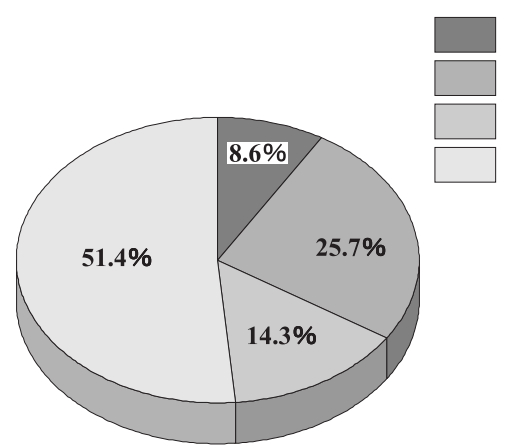

FFDM（腫瘤と認識された35例中）

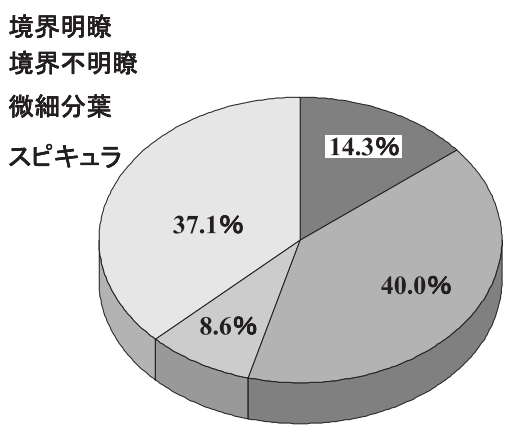

SFM（腫瘤と認識された35例中）

図 3. 腫瘤辺縁の性状

代表的な画像をそれぞれ図 6,7 に示す。

\section{3. 考 察}

欧米での乳癌検診における SFM の導入により50歳 以上では死亡率が16３5\%低下し，その有用性が実証 された
年 3 月から50歳以上の女性における乳癌検診にはマン モグラフィが併用されるようになった。40歳台でも同 様の臨床試験が実行され，有用性は証明されたものの 死亡率の軽減は15～20\%にとどまった5)。その理由と して, 欧米では乳癌罹患年齢が50歳以降にピークが存 在すること, および40歳台には高濃度乳腺の比率が高 
FFDM (30例)

スピキュラ

微細分葉、鋸歯状

不明瞭

明瞭
SFM (30例)

スピキュラ

微細分葉、鋸歯状

不明瞭

明瞭

図 4. 両モダリティ間の腫瘤辺縁の対比

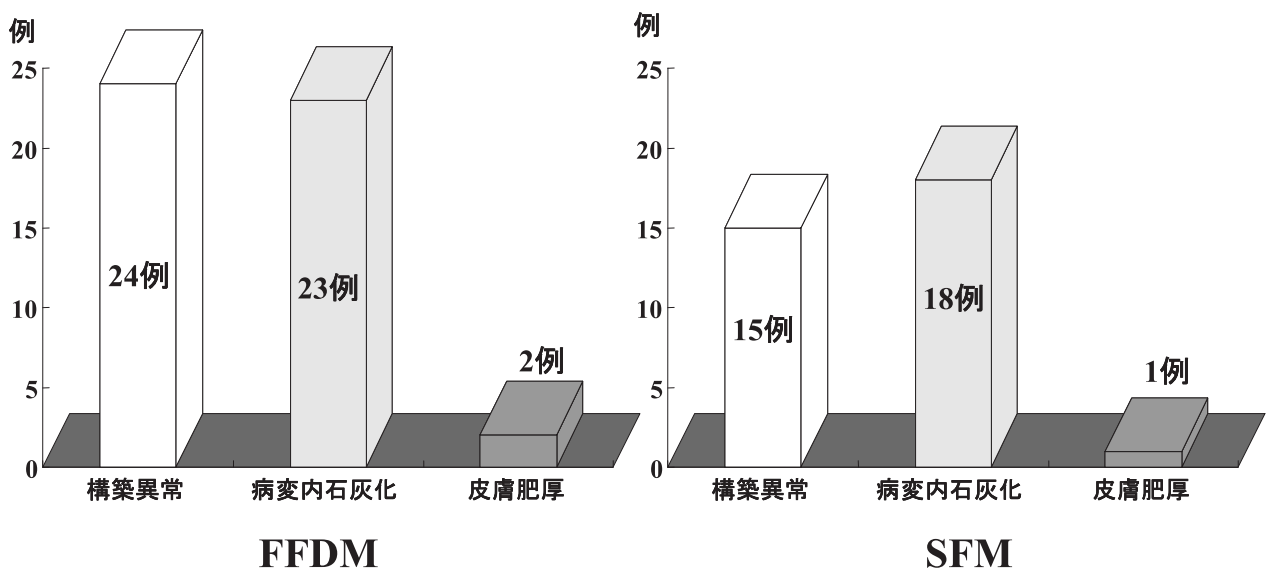

図 5. 随伴所見

いことなどが考えられている6 。一方，FFDM の有用

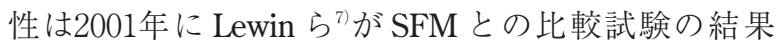
を報告したことから始まり，さらにO Slo II 試験や DMIST な゙により安全性も含めてより確実なものと なった。近年デジタルマンモグラフィ撮影装置は国産 機種も登場し, 多数の機種が存在する。SFMに近い 画像を提示する機種もあれば，いかにもコンピュータ 画像といったものもあり，ひとえにデジタルといって も多種多様である。この点に関しては, DMISTにて, 癌の診断精度は機種間で有意差は認めなかったと報告 されており ${ }^{1)}$ われわれが使用した機種も同試験に含 まれていたため，今回の結果には撮影装置そのものの 性能は除外し, 一般的なデジタル撮影装置として考察 できるものと判断する。

今回のわれわれの結果では, 病変の存在診断のみな らず，その診断内容も FFDM がSFMに勝っていた。 つまり, FFDM ではカテゴリー4, 5 と判断できるケ 一スが有意に多く認められた。さらに, 背景乳腺が高 濃度であるほどその差が顕著であった。そもそもデジ
タルマンモグラフィの検出器から得られる画像信号は フィルムよりもきわめて広いダイナミックレンジを有 しているが, その特性曲線は直線的であり, 読影可能 な画質にするために種々の画像処理がなされる。一般 的には, 階調処理, 周波数処理, ダイナミックレンジ 圧縮処理などであるが，そのほかにも各社それぞれに 特徵的な処理方法がある。ただ総括して言えること は，デジタルではこれらの処理により石灰化や腫瘤の 辺縁がSFMよりかなり強調され, さらに病変の視認 性を向上するために乳房内コントラストを大きくして いる8)。40歳〜 50歳台に罹患率のピークを有し，さら に高濃度の頻度が高い本邦に扔いては, FFDMのこ の特性は大いに期待される。今回のわれわれの結果で も, 腫瘍辺縁に関しては, FFDMにて SFMに比し境 界不明瞭の頻度が少なかったこと, 拈よび癌としての 特異度の高い微細鋸歯状, スピキュラと診断できた症 例がSFMに比べて有意に多かった。つまり, FFDM で辺縁診断に関する視認性が良好であると考えられ た。さらに, SFMに比較して FFDM で構築の乱れや 


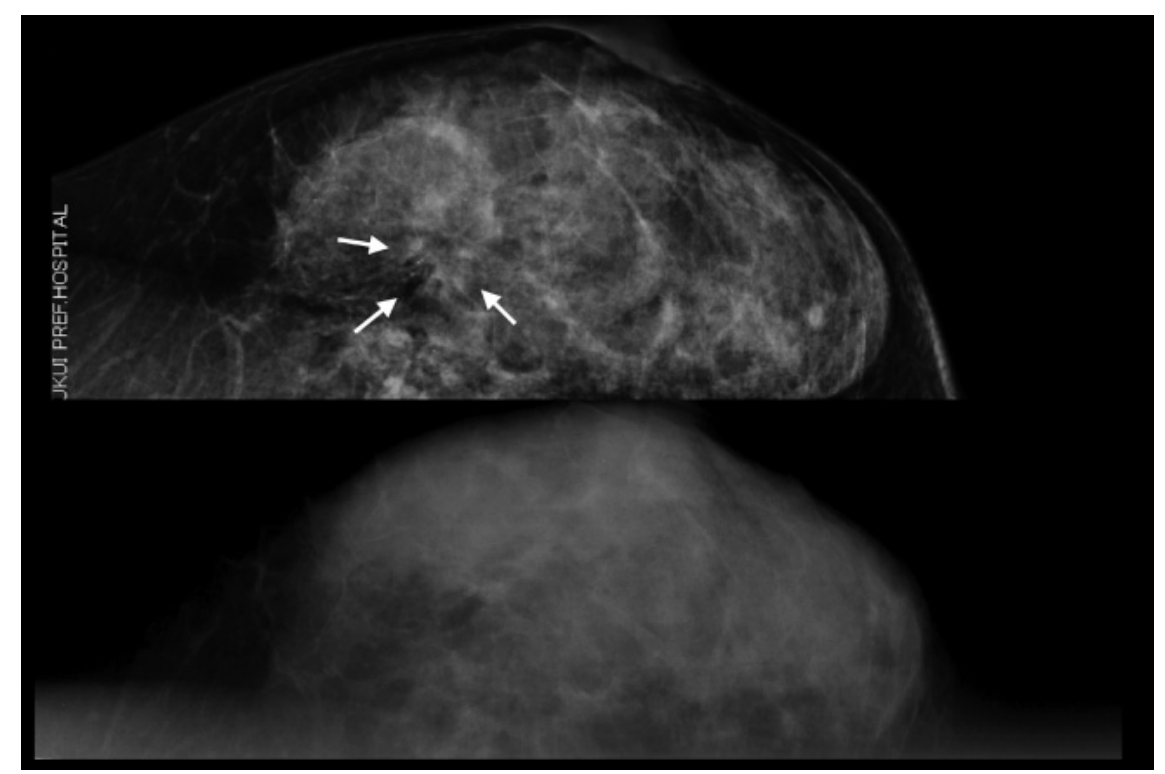

図6. $1.8 \mathrm{~cm}$ 大の浸潤性乳管癌症例：写真右側の FFDM では, 腫瘤影は認めないが,

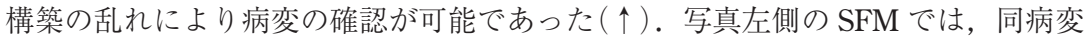
の確認は困難であった。

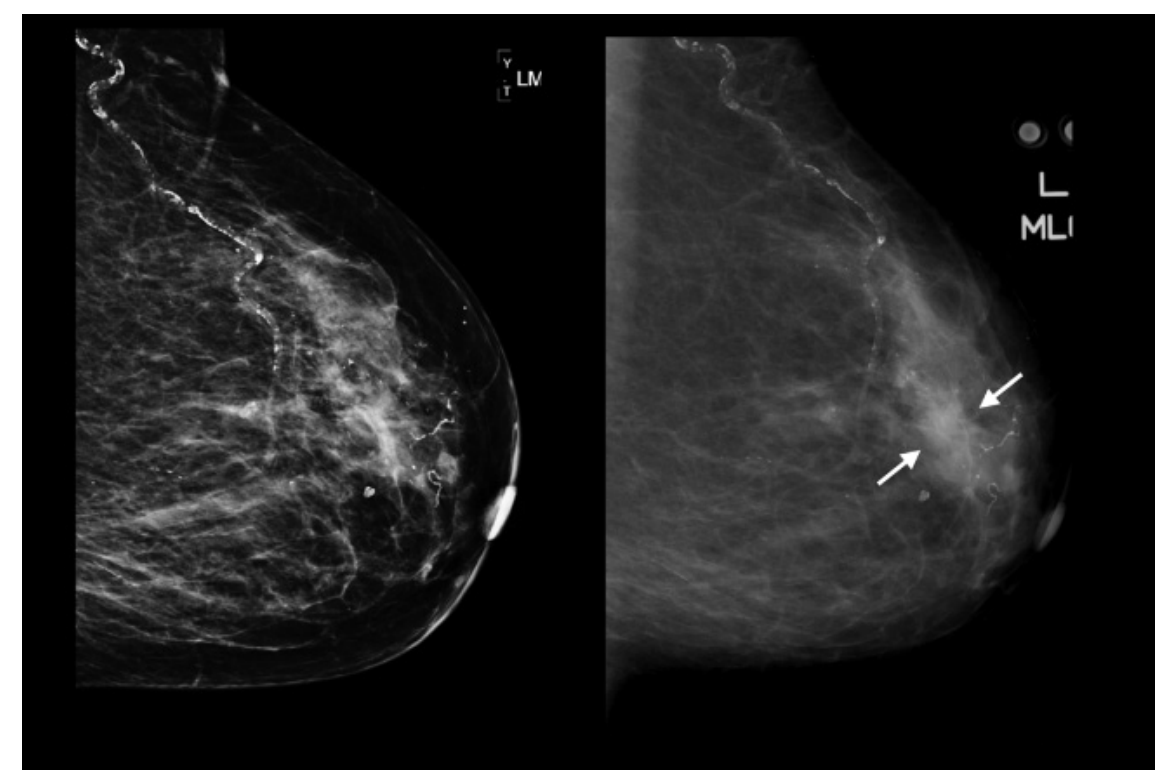

図7. $3.8 \mathrm{~cm}$ 大の非浸潤性乳管癌症例：写真右側の SFM では，濃度が高いことより 病変の確認が可能であった $(\uparrow)$. 写真左側の FFDM では, 同病変の確認は困難で あった。

石灰化などの随伴所見が高率に確認できており，これ らの結果が癌の存在診断やカテゴリー診断に良い影響 を与えたものと判断された。FFDMでの視認性の良 さは，無症状の女性42,760名を対象としたDMISTに おいても証明されている。同試験では, SFM と FFDM の間には診断精度の差は認めなかったが, 50歳未満, もしくは高濃度乳腺, 閉経前症例に限定した場合, 診 断精度は有意にFFDM で良好であり，病変の内訳も 浸潤癌や悪性度の高い DCIS でより顕著であった。

一方, 今回の結果では, FFDM で 5 例, SFM で 7 例の偽陰性症例を認めた (表 2,3$)$ 。FFDM 偽院性症例
の60.0\%がDCIS であり，それらはSFMにて病変内 部に石灰化を認めない等濃度腫瘤や $\mathrm{FAD}$ のみで描出 される病変であった。一方, SFM 偽陰性症例の $85.7 \%$ が浸潤癌であり，それらはFFDM では構築の乱れや スピキュラ, 病変内部の石灰化など比較的癌としての 特異度の高い所見が多く見受けられた。SFMで浸潤 癌が偽陰性となった原因としては, 背景の高濃度乳腺 に病変が隠れたためと判断された。一方，石灰化など の随伴所見をまったく有さない陰影のみの DCIS に関 しては，確かにFFDM で劣勢を示した。Oslo II 試験 でも同様に, 浸潤癌の検出率ではあらゆる年齢層で 
FFDM が有意に高いが，DCIS では有意差はないもの の，SFMで良好との結果が報告され，われわれの結 果と一致していた。この原因として，FFDMでは乳 腺外のコントラストが小さい傾向にあり，比較的濃度 の低い病変は目につきにくい傾向にある ${ }^{9)}$ 。乳腺外の コントラストをえるためのパラメーターを調整する 等, 今後の課題と考えられるが, 実際には陰影のみで 発見される DCIS は比較的少なく，検診では大部分が 石灰化や, 触知腫瘤, 乳頭異常分泌などより発見され ている ${ }^{10)}$ 。今回のわれわれの結果では, FFDMのもう 1 つの側面である浸潤癌の同定率の高さをより重要視 すべきと思われた。

\section{結 語}

FFDM では，生命予後に関わる浸潤癌の検出力は SFM を凌駕しており，そういった意味ではFFDMの 存在価值を十分に証明できたものと思われる。一方， 石疢化やその他の所見のない陰影たけのDCIS は FFDM にとって今後の課題であり, メーカーと協力 の上，新たなパラメーターの調整などが必要と考えら れた。

今回のデータは, 両モダリティともに全例癌診断後 に行われた再読影の結果であり，病変の存在を知った 上での作業であるゆえに読影に少なからず影響が及ん でいることは否定できない。よって本検討の結果を実 証すべく, 複数読影者によるブラインド下での研究を 試みるつもりである。

\section{【文 献】}

1) Pisano ED, Gatsonis C, Hendrick E, et al: Diagnostic performance of digital versus film mammography for breast-cancer screening. N Engl J Med, 353: 2005

2 ) Skaane P, Skjennald A: Screen-film mammography versus full-field digital mammography with soft-copy reading: randomized trial in a population-based screening program-The Oslo II Study. Radiology, 232: 197-204, 2004

3 ) 角田博子：フルデジタルマンモグラフィのモニタ診 断. 乳癌の臨床, $21: 263-269,2006$

4 ) Humphrey LL, Helfand M, Chan BK, et al: Breast cancer screening: a summary of the evidence for the U.S. Preventive Services Task Force. Ann Intern Med, 137: 347-360, 2002

5 ) Fletcher SW, Elmore JG: Mammographic screening for breast cancer. N Engl J Med, 348: 1672-1680, 2003

6 ) Buist DSM, Porter PL, Lehman C, et al: Factors contributing to mammography failure in women aged 40-49 years. J Natl Cancer Inst, 96: 1432-1440, 2004

7 ) Lewin LM, Hendrick RE, D’Orsi CJ, et al: Comparison of full-field digital mammography with screen-film mammography for cancer detection: Results of 4,945 paired examinations. Radiology, 218: 873-880, 2001

8 ）大内憲明：実践デジタルマンモグラフィ——基礎から 診断まで——. 中山書店, 東京, 2006, pp. 2-19

9 ）大内憲明：実践デジタルマンモグラフィ一一基礎から 診断まで——. 中山書店, 東京, 2006, pp. 118-119

10）荻谷朗子, 堀井理絵, 大迫 智, 他: 非浸潤性乳管癌 の発見契機別形態学的特徵. 乳癌の臨床, $23: 531-$ 535,2008 


\title{
Comparison Between Full-field Digital Mammography and Screen Film Mammography for Detection of Breast Carcinomas
}

\author{
${ }^{1}$ Kouji Ohta, MD, ${ }^{2}$ Yuko Nishide, MD, 'Hirotaka Kitamura, MD, ${ }^{3}$ Yasuharu Kaizaki, MD \\ Departments of ${ }^{1}$ Surgery, ${ }^{2}$ Radiology and ${ }^{3}$ Clinical Pathology, Fukui Prefectural Hospital, Fukui, Japan
}

To investigate the characteristics of full-field digital mammography (FFDM) in comparison with screen film mammography (SFM), we compared the results of interpretation between FFDM and SFM in 64 patients with breast carcinoma who were preoperatively examined using both modalities. In FFDM, the flat panel detector was adopted, and double reading was performed using a 5-megapixel liquid crystal display monitor. The mass margins, associated findings such as architectural distortion or micro-calcification, and categories were compared. Identification of the lesion was difficult in $7.8 \%$ of cases by FFDM and in $10.9 \%$ by SFM. The category was 4 or 5 in $78.2 \%$ by FFDM and in $70.3 \%$ by SFM ; diagnosis was more accurate using FFDM. The mass margins were microlobulated or spiculated, being highly specific to cancer, in $65.7 \%$ of cases by FFDM and in $45.7 \%$ by SFM, allowing more detailed diagnosis by FFDM. Associated findings were revealed in $59.4 \%$ of cases by FFDM but in only $45.3 \%$ by SFM. Isodense DCIS without associated findings accounted for $60 \%$ of the lesions not identified by FFDM, while small invasive carcinoma accounted for $85.7 \%$ of those not identified by SFM. FFDM was superior to SFM in its ability to detect invasive carcinoma affecting survival.

Key words: full-field digital mammography, screen film mammography, breast carcinoma 